\title{
A debris-flow alarm system for the Alpine Illgraben catchment: design and performance
}

\author{
Alexandre Badoux Christoph Graf · Jakob Rhyner · Richard Kuntner • \\ Brian W. McArdell
}

Received: 20 March 2008/Accepted: 5 October 2008/Published online: 7 November 2008

(C) Springer Science+Business Media B.V. 2008

\begin{abstract}
We describe the development, implementation, and first analyses of the performance of a debris-flow warning system for the Illgraben catchment and debris fan area. The Illgraben catchment $\left(9.5 \mathrm{~km}^{2}\right)$, located in the Canton of Valais, Switzerland, in the Rhone River valley, is characterized by frequent and voluminous sediment transport and debris-flow activity, and is one of the most active debris-flow catchments in the Alps. It is the site of an instrumented debris-flow observation station in operation since the year 2000 . The residents in Susten (municipality Leuk), tourists, and other land users, are exposed to a significant hazard. The warning system consists of four modules: community organizational planning (hazard awareness and preparedness), event detection and alerting, geomorphic catchment observation, and applied research to facilitate the development of an early warning system based on weather forecasting. The system presently provides automated alert signals near the active channel prior to (5-15 $\mathrm{min}$ ) the arrival of a debris flow or flash flood at the uppermost frequently used channel crossing. It is intended to provide data to support decision-making for warning and evacuation, especially when unusually large debris flows are expected to leave the channel near populated areas. Firstyear results of the detection and alert module in comparison with the data from the independent debris-flow observation station are generally favorable. Twenty automated alerts (alarms) were issued, which triggered flashing lights and sirens at all major footpaths crossing the channel bed, for three debris flows and 16 flood flows. Only one false alarm was issued. The major difficulty we encountered is related to the variability and complexity of the events (e.g., events consisting of multiple surges) and can be largely solved by increasing the duration of the alarm. All of the alarms for hazardous events were produced by storms with a rainfall duration and intensity larger than the threshold for debris-flow
\end{abstract}

A. Badoux $(\bowtie) \cdot$ C. Graf · B. W. McArdell

Swiss Federal Institute for Forest, Snow and Landscape Research WSL,

Zürcherstrasse 111, 8903 Birmensdorf, Switzerland

e-mail: badoux@wsl.ch

J. Rhyner

WSL Institute for Snow and Avalanche Research SLF, Davos, Switzerland

R. Kuntner

Teysseire \& Candolfi AG, Visp, Switzerland 
activity that was defined in an earlier study, supporting our intention to investigate the use of rainfall forecasts to increase the time available for warning and implementation of active countermeasures.

Keywords Alarm system - Debris-flow detection - Debris-flow observation · Rainfall intensity-duration threshold · Hazard awareness · Swiss Alps

\section{Introduction}

Due to their large flow velocity, impact forces, and long runout distances, debris flows are one of the most hazardous landslide types in mountainous regions. In the Swiss Alps over the last 30 years an average of 17 damage-causing debris flows per year has been documented (Schmid et al. 2004). They tend to occur during large regional storm events every few years. The cost of constructed mitigation measures is quite large, especially considering that Alpine communities are also threatened by other processes such as flooding, landslides, rockfall, and snow avalanches, indicating the need for low-cost measures such as alarm systems. In this paper we describe the development and performance of such an alarm system, which has been implemented at one of Switzerland's most active debris-flow torrents, the Illgraben (Rickenmann et al. 2001).

A debris flow is a gravity-driven, fast-flowing mixture of water and soil debris in high concentration, with a flow behavior intermediate between floods and landslides (e.g., Iverson and Vallance 2001), typically occurring in several surges. Debris-flow surges characteristically have boulder-rich fronts that are comparatively free of matrix soil debris (Pierson 1986) whereas the main body of the event is a finer mixture of liquefied soil debris. Debris-flow initiation requires an abundant source of unconsolidated regolith, steep slopes, and a source of moisture. Most commonly, moisture is from intense or prolonged rainfall, rapid snowmelt, or a combination of the two which produces significant water discharge and sediment entrainment on the channel bed. If sufficient soil moisture is present, debris flows can be generated by the mobilization of channel deposits or landslides (Costa 1984). However, earthquakes and dam failures can also trigger debris-flow events.

Due to their sudden initiation, debris flows are difficult to predict (e.g., Sidle and Ochiai 2006) and even small events can endanger humans and infrastructure. Warning systems are foreseen to provide some degree of protection, mainly to prevent fatalities. Many systems have been developed for densely populated mountainous areas throughout the world. Recent examples are available from Canada (Jakob et al. 2006), Italy (Bacchini and Zannoni 2003), Taiwan (Chang 2003; Chen et al. 2005; Kung et al. 2008), China (Brand et al. 1984; Zhang 1993), and Japan (Hirano 1997; Itakura et al. 1997; Tanabashi 1998).

In this article we illustrate the debris-flow hazard situation near an Alpine community at the Illgraben torrent. This site has been intensively monitored for debris-flow activity since 2000 (Hürlimann et al. 2003, McArdell et al. 2007) and was selected for research partially because debris flows constitute a significant hazard for the community of Susten (municipality of Leuk). A multi-stage alarm system was developed (Graf et al. 2007) to allow adequate alerting for frequent small events and still provide reliable warning for infrequent large events. We describe the performance of the system for the small events for the first year of operation (2007), discuss its limitations and describe planned developments, and identify the areas where further research is needed. 


\section{Debris-flow detection and alarm systems}

Debris-flow detection and warning systems are in widespread use. Relatively simple systems that detect flows (e.g., Bacchini and Zannoni 2003; Chang 2003; Liu and Chen 2003) include a wide range of detection sensors such as geophones (ground vibration), ultrasonic and radar distance measuring devices (flow height), or microwave sensors (water table variation), and they may be linked to traffic lights or alarm signals to notify the authorities who are responsible for natural hazard management. The travel time between the initiation zone and the arrival of the front at a point of interest is typically much less than an hour. While trains, vehicles, and pedestrians can often be warned to leave or at least not enter an endangered area, a real-time monitoring system does not provide enough time for the evacuation of residents from such an area. Hence, there is the need for reliable prediction to provide early warning for all debris flows with a minimum of false alarms. Complete safety will never by guaranteed by such systems, which in general should be considered from a risk management perspective. However, risk management is not addressed in this paper.

Given that there are no internationally recognized definitions for warning and alert, we follow the Swiss regulations where warning or early warning is defined as timely information on a possible hazardous event, and alert is considered to be an acoustic (and visual) signal in case of immediate danger, with the goal to initiate a predefined reaction of the affected population.

Early warning systems for debris flows often combine rainfall forecasts and real-time measurements of precipitation, and typically use empirical rainfall thresholds for mass movement activity, which are ideally available for the region under consideration (e.g., Wieczorek 1987; Deganutti et al. 2000; Fan et al. 2003).

The U.S. Geological Survey (USGS) in cooperation with the National Weather Service (NWS), operated one of the first experimental debris-flow prediction and warning systems in the San Francisco Bay area from 1986 to 1995 (Keefer et al. 1987; Wilson et al. 1993) based on rainfall thresholds established for this region (e.g., Cannon and Ellen 1985; Wilson and Wieczorek 1995). This system relied on a combination of precipitation forecasts, rainfall measurements, and comparison with the empirical rainfall thresholds, which provided early warning times of at least several hours before the rainfall thresholds were exceeded. California is also subject to debris-flow activity on areas that have recently been burned by wild fires-a well-elaborated concept for such a warning system, including research needs, has been described in a report by the NOAA-USGS Debris Flow Task Force (2005). The triggering rainfall events in this case are intense long-duration events for which the availability of accurate forecasts may increase the reliability of warnings in comparison to the very intense short-duration storms that often trigger Alpine debris flows (e.g., Berti and Simoni 2005; Gregoretti and Dalla Fontana 2007).

The Geotechnical Engineering Office in Hong Kong installed a warning system for shallow landslides in 1977. Steady improvement led to a completely automated system for landslide forecasting based on short-term precipitation forecasts for the area (Chan and Pun 2004; Aleotti 2004). In their system, data from more than 100 rain gauges, rainfall radar, and satellite images are used to monitor the weather situation. When the 1 or $24 \mathrm{~h}$ rainfall thresholds are exceeded, local broadcasting services begin transmitting regular warning messages to the public.

Jakob et al. (2006) investigated the possibility of predicting the timing of debris flows along the British Columbia north coast to protect forestry workers and their equipment. However, the large degree of spatial variability and limited number of long-term 
measurements made it impossible to apply traditional methods. Therefore, a decision tree for landslide advisories was established including regional precipitation forecast, 4-week antecedent rainfall, and local 24-h rainfall data combined with a storm classification scheme. The resulting warning level indicates the degree of landslide susceptibility, thereby providing a support tool for the responsible parties.

These early warning approaches strongly depend on the quality of the forecast and predictive capability of the rainfall thresholds which are often imprecise, especially in alpine environments where short and local thunderstorms are likely to trigger debris flows.

\section{The Illgraben catchment}

The Illgraben catchment ( $a r e a=9.5 \mathrm{~km}^{2}$ ), situated near the village of Susten (municipality Leuk) in the Canton of Valais, is characterized by a high degree of sediment transport and debris-flow activity (Figs. 1,2). Forty four percent of the catchment is covered by bedrock and debris deposits, $42 \%$ by forest, and $14 \%$ by grassland. The catchment ranges in elevation from the summit of the Illhorn mountain (2716 $\mathrm{m}$ a.s.1.) to the fan apex (850 $\mathrm{m}$ a.s.1.) to the outlet at the Rhone River (610 $\mathrm{m}$ a.s.1.). The main torrent channel (the Illgraben torrent) flows $3 \mathrm{~km}$ to the northeast through the active part of the catchment until the fan apex (through observation sectors 2 and 3 in Fig. 2) and an additional $2 \mathrm{~km}$ then north along the center of the fan (through sector 1). The mean slope of the entire Illgraben torrent channel is $9^{\circ}(16 \%)$ decreasing to $10 \%$ downstream of the fan apex. The Illgraben debris fan is a prominent landform in the Rhone River valley with a radius of about $2 \mathrm{~km}$ and a volume estimated at $500 \times 10^{6} \mathrm{~m}^{3}$. The Illbach sub-catchment (east of the Illgraben torrent, not shaded in Fig. 2) is much less active and has a smaller

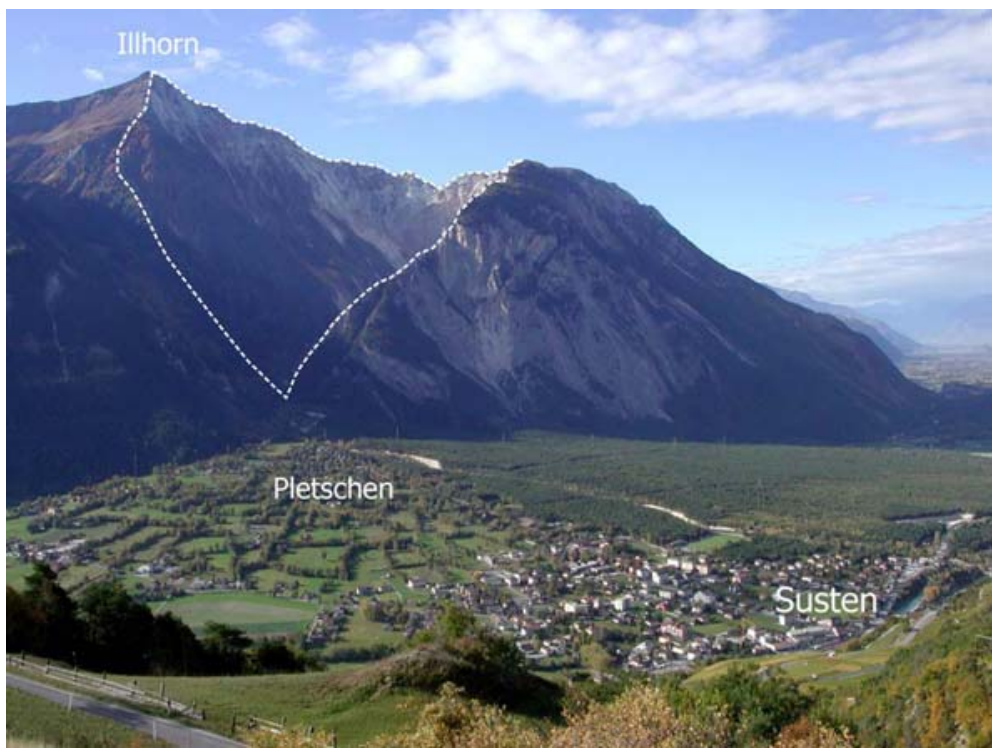

Fig. 1 Illgraben debris fan with the village of Susten and the confluence with the Rhone River in the foreground and the catchment in the background (F. Dufour, WSL). The area enclosed by the dashed line shows the active part of the catchment corresponding to observation sectors 2 and 3 on Fig. 2 


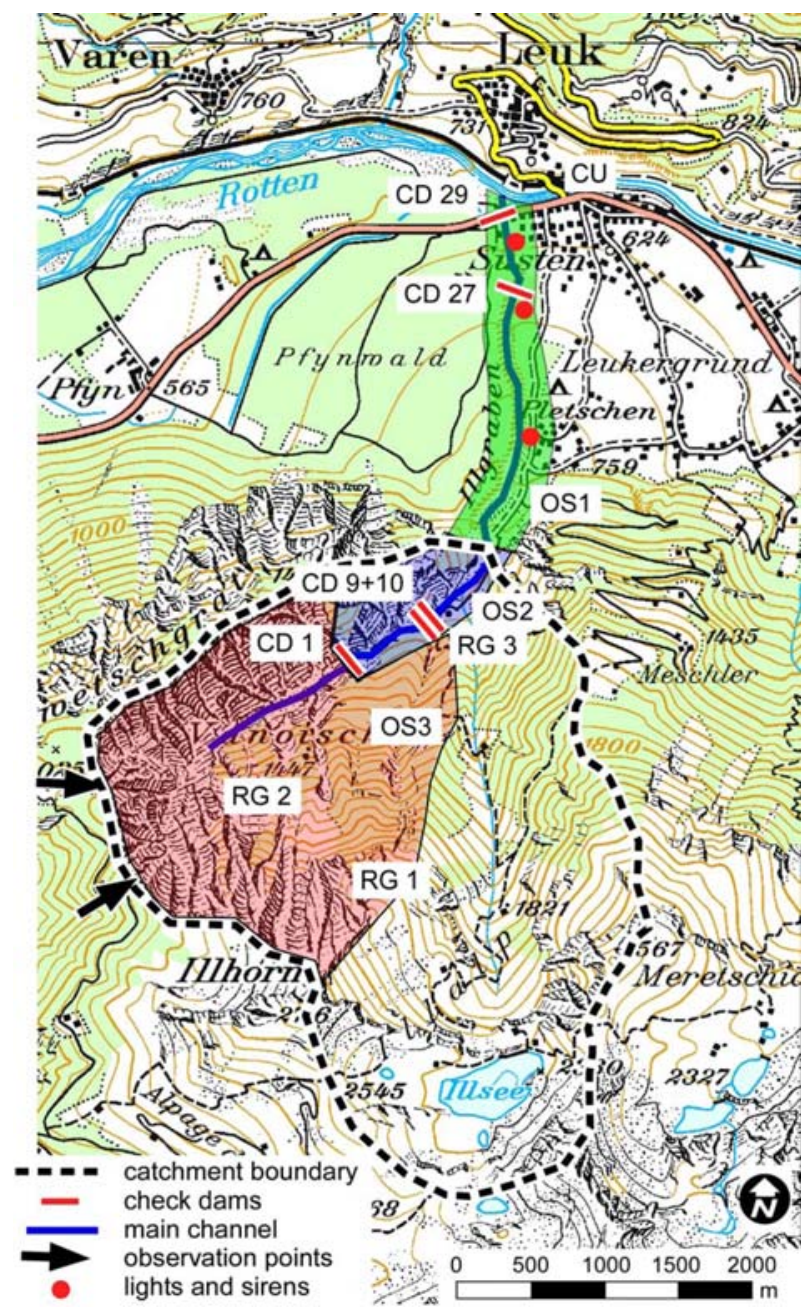

Fig. 2 Overview of the study area showing the location of the detection system at check dams 1 (CD1), 9 and $10(\mathrm{CD} 9+10)$, the location of the rain gauges $(\mathrm{RG})$, communication unit (CU), alert lights (red dots), observation sectors (OS), and observation points. The shading indicates the different observation sectors (OS1 in green, OS2 in blue, and OS3 in red). Map reproduced with the permission of Swisstopo (JA082265)

channel, partially due to the fact that drainage in the upper part of the catchment has been diverted for hydropower, and no field evidence of debris-flow activity is evident. The eastern side of the fan is inhabited, with both year-round and vacation housing, a campground, and various other recreational facilities such as tennis courts and a football field. The village of Susten on the lower part of the fan is densely populated $\left(\sim 300\right.$ people $\left./ \mathrm{km}^{2}\right)$. The riparian zones are used frequently by pedestrians and people on horseback. The western side of the fan is a natural area that attracts a large number of visitors every year.

The Illgraben catchment is the site of a debris-flow observation station operated by the Swiss Federal Institute for Forest, Snow and Landscape Research WSL (Rickenmann et al. 2001; Hürlimann et al. 2003; McArdell et al. 2007). Several flood and debris-flow events 

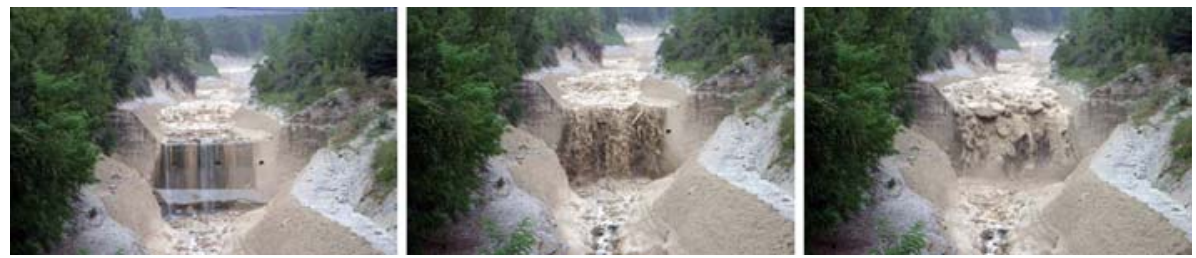

Fig. 3 Arrival of the debris-flow front upstream of check dam 29 during the July 28, 2006 event (C. Gwerder, WSL)

are observed each year. We have recorded a wide variety of flow types ranging from granular debris flows (Fig. 3) to muddy debris flows, to hyper-concentrated flows and flood flows. All of these have been observed on video recordings to transport boulders with a mean diameter as large as the flow depth. Many of the floods occur as flash floods where the stage rises from zero to up to several meters within a few seconds or minutes. The largest documented event with a total volume of several hundred thousand cubic meters occurred on June 6,1961 and caused considerable damage on the lower part of the fan (Figs. 4a, b).

Instrumentation along the lower-most $1 \mathrm{~km}$ of the channel includes geophones (for front velocity determination and system triggering), radar, laser, and ultrasonic devices to determine flow depth, video cameras, and a debris-flow force plate. The observation station is complemented by three rain gauges (presently owned and operated by the Cantonal government) that are situated in the catchment area on the flanks of the Illhorn mountain. Here, we use data only from gauge 1 (Fig. 2) because it is the most reliable one. As described in more detail below, the WSL debris-flow observation station is operated independently of the alarm system discussed in this paper.

The triggering mechanisms associated with the occurrence of debris flows in the Illgraben are not fully known yet due to the inaccessibility of the upper catchment. However, debris-flow initiation mechanisms are the topic of a newly funded project at the Illgraben and considerable progress in the understanding of these processes is expected. Taking into account these limitations, a few statements can still be made.

Based on historical evidence, the largest debris flows likely to take place at the Illgraben are associated with the rapid formation and catastrophic failure of lakes formed by landslides within the source area (or perhaps following exceptionally large rainfall events). The failure of such a dam is not directly connected to a certain type of rainfall event and can be caused by high-intensity short duration storms or long-duration precipitation with low intensities. This scenario probably led to the June 6, 1961 debris flow mentioned above, the largest historical event observed at the Illgraben. Other possible debris-flow triggering mechanisms in the upper Illgraben catchment (main channel or smaller side channels draining the north-west facing slopes of the catchment) include, sediment entrainment and bulking produced by runoff in rills and channels, transformation of shallow landslides including landslides forming within the channel bed, and the mobilization of channel sediment below a rock face that collects and concentrates runoff (cf. Godt and Coe 2007). According to ongoing studies in the Illgraben (McArdell and Badoux 2007) as well as other studies in the steep Alpine environment (e.g. Gregoretti and Dalla Fontana 2007; Berti and Simoni 2005), high-intensity short-duration burst rainfall is more likely to mobilize debris deposits in channels than low-intensity precipitation events. However, the formation of debris flows is also possible under intermediate or even low-intensity 

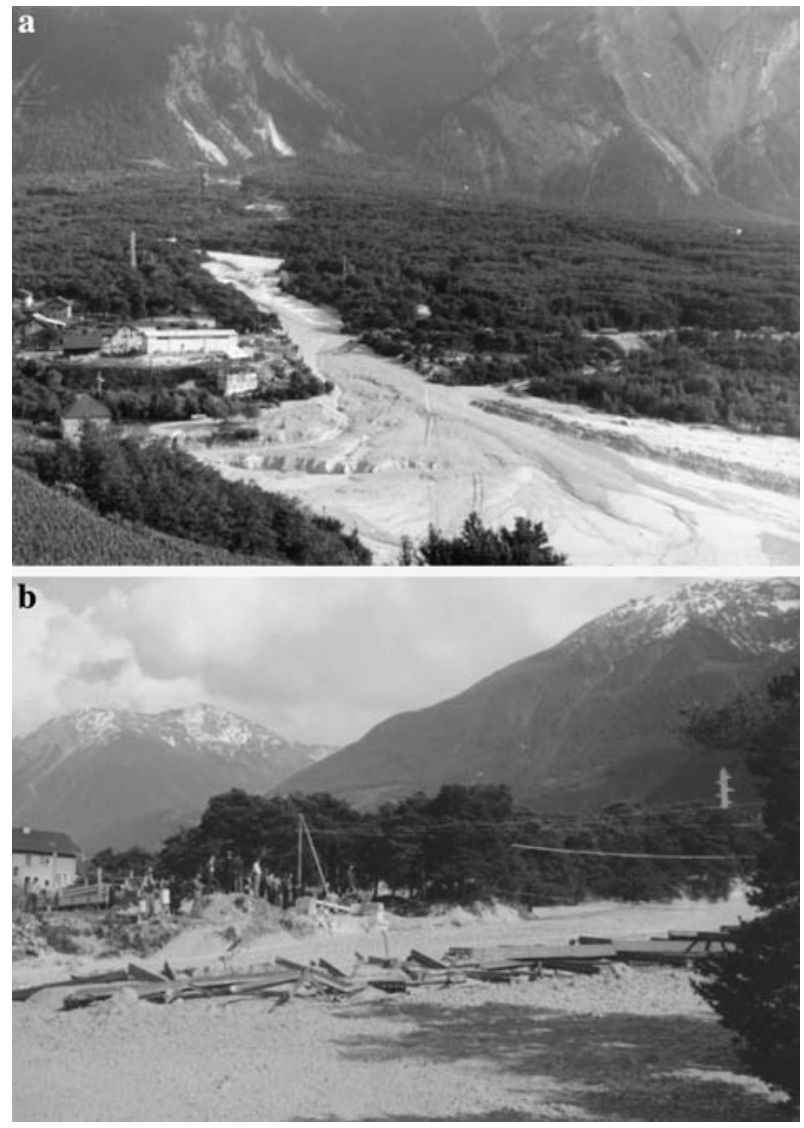

Fig. 4 a Illgraben debris fan after the largest-known debris flow (June 3, 1961) with a volume of approximately $500,000 \mathrm{~m}^{3}$ that overflowed the banks of the Illgraben channel (Kreisforstamt IV, Canton of Valais). b The event destroyed the road bridge crossing the channel on the lower part of the debris fan (Kreisforstamt IV, Canton of Valais)

precipitation conditions (due to e.g., mobilization of small lateral landslides or after large landslides damming the channel as described above) and may be associated with snowmelt during the spring season.

Debris flows at the Illgraben can generally be grouped into small debris flows that remain entirely within the channel, large debris flows that may reach populated areas, and intermediate flows with limited overbank flow. Although other flow size criteria such as peak discharge or flow depth may be equally useful, for historical reasons (e.g., event data from the past) for the initial planning of the warning system we used event volume to differentiate between flows of different expected sizes.

Although a small debris flow does not overtop the channel banks, it still constitutes a hazard for people in or near the channel. This definition varies with time because the elevation of the bed, and therefore the capacity of the channel changes due to progressive deposition or erosion on the channel bed. Records of channel-bed elevation or channel capacity are generally unavailable, therefore the upper volume limit for small debris flows has been estimated using unpublished consulting reports at $75,000 \mathrm{~m}^{3}$. No flow has 
overtopped the channel banks since the installation of the debris-flow observation station in June 2000.

Intermediate events between $75,000 \mathrm{~m}^{3}$ and $250,000 \mathrm{~m}^{3}$ are infrequent and the extent of overbank flow depends partially on the capacity of the channel. Several debris flows with intermediate volumes are expected in 100 years. During periods when the channel bed is relatively high in elevation it is possible that an intermediate-size flow may exceed the channel capacity along some reaches of the debris fan below the fan apex. Numerical simulations using the DFEM-1D debris-flow runout model (Naef et al. 2006) indicate overbank flow along the reach near Susten.

Large debris flows constitute a hazard for both the riparian zones and populated areas on the debris fan. Based on limited historical data (mainly one event in 1961), large debris flows are defined to have a volume of at least $250,000 \mathrm{~m}^{3}$. Geomorphic catchment observation, including estimating the capacity of the channel on the fan, is important for large debris flows because when the capacity of the channel is exceeded such flows may reach populated areas. Numerical simulations (described earlier) indicate overflow at the village of Susten and additionally near a campground and vacation houses (the Pletschen area, Figs. 1 and 2). As discussed above, large debris flows are probably associated with the rapid formation and catastrophic failure of landslide lake dams. Because it is impossible given current technology and available resources to predict their formation, it is unlikely that it will be possible to provide sufficient warning to initiate any evacuation plan unless the landslide dam is identified beforehand. Such events represent a residual risk that we cannot further reduce with the state of technology today.

\section{The alarm system}

\subsection{Objectives and setup}

A protection concept to reduce the debris-flow risk for the Illgraben was initiated in 1999. One aim is to incorporate several types of protection measures as recommended in the Swiss guidelines for flood control issued by the Federal Office for Water and Geology (now the Federal Office for the Environment). The alarm system, part of the protection concept, is intended to minimize the risk associated with debris flows until planned structural measures are completed, and to reduce the residual risk after construction. Alarm systems for debris flows in Switzerland are not yet widespread. Generally the communities are responsible for crisis management (e.g., the evacuation of buildings) at the local level. The responsibility for the generation and broadcasting of the warning and for the development and maintenance of the corresponding infrastructure is shared among the communal, cantonal and the federal levels. The management and maintenance of the local infrastructure of the Illgraben alarm system will become the responsibility of the community after completion of the project, by the end of 2008 .

The alarm system presented herein is loosely based on the extensive experience in prediction, warning, and alarm systems for snow avalanches (e.g., Bründl et al. 2004), which have many features in common with debris flows. The success of avalanche warning is due to a widespread awareness of avalanche danger, a well-designed observation and information system (including daily avalanche bulletins), and a significant correlation between weather conditions and avalanche triggering, enabling regional-scale prediction. Avalanche detection systems in some exceptionally hazardous initiation zones activate warning signals on roads and railway lines crossing the avalanche track, and are successful 
even though the lead time is only on the order of a few minutes (e.g., McClung and Schaerer 1993; Gubler 1996; Decker et al. 1997).

Several differences between snow avalanches and debris flows make direct transfer of experience difficult. For example, for Alpine debris flows the triggering weather event is often short-duration very intense rainfall, which is difficult to predict. Nevertheless, some elements of the Swiss avalanche warning system are useful and are reflected in the four modules defined for the Illgraben alarm system:

(1) Organizational measures in the community: dissemination of information to tourists and residents, education (in the schools) on debris-flow hazards, compilation of alerting/alarm procedures (flow charts), and in a later stage the planning of active measures in the case of an expected large overbank debris flow.

(2) Detection system: automatic alarm generation for hazardous floods and debris flows.

(3) Catchment observation: systematic observation of the catchment including the compilation of a database of geomorphic changes.

(4) Weather forecasting: improvement of local short- to medium-term precipitation forecasts as well as short-term radar-supported precipitation forecasts as a basis to assign an occurrence probability for debris flows.

The first three modules were implemented in 2006 and 2007. Within module 3 a progressively growing database of observations will permit analysis and support decision making, especially regarding events such as channel-blocking landslides. However, it will require a few years of data before it is useful. Module 4 requires a longer development time than the others; the long-term goal is to provide a basis for issuing warnings based on occurrence probability. The modules are described in more detail in the next sections.

\subsection{Organizational protection measures}

\subsubsection{Permanent organizational measures}

This module aims to create awareness among the local population and tourists. During the debris-flow season (April to October) pedestrians crossing the Illgraben torrent channel and entering the channel bed expose themselves to a non-negligible risk. Flow events can occur at any time, also when there is no precipitation (e.g., during snowmelt) or when the precipitation is limited to the uppermost part of the catchment such as during a thunderstorm. Although residents are largely aware of the correlation between heavy rainfall and debris flows because the vibrations can be felt in parts of the village, the channel riparian zones are heavily used and are also frequented by tourists.

April to October is the main tourist season. Due to the large and popular forested nature reserve covering the western part of the debris fan, hiking, cycling and horseback riding are quite common activities. To inform these people warning signs were installed on average every $200 \mathrm{~m}$ along both sides of the channel from the fan apex to the confluence with the Rhone River. The signs indicate the risks related to the crossing of the channel bed and advise leaving the channel bed as quickly as possible. The text is in the five languages most frequently used by tourists and local residents, German, French, Italian, English, and Dutch. At three frequently used crossings, optical and acoustic alert signals were installed which are activated by the detection system described below. The travel time of a debris flow from the upstream-most detection unit to the first alert installation ranges from 5 to 15 min depending on the properties of the flow. In addition, all new channel bed crossings are regularly made impassable by municipal workers. 
An information-dissemination concept has been established within the project. Many of the visitors can be informed through the local tourism industry. Within this module of the project, tourists are to be addressed using flyers distributed by the operators of the tourist infrastructure. Annually at the beginning of the debris-flow season the local newspaper reports on the debris-flow events of the previous year and reminds the readers of the risk associated with lingering in the channel bed. The local primary school holds information events and field visits regularly.

\subsubsection{Organizational measures in the case of an event}

In the case when large debris flows are expected, such as an unusually large approaching storm system or the occurrence of a new landslide dam in the initiation area or low channel capacity, sufficient time is available to implement organizational mitigation measures. At the Illgraben, local decisions are made by the Municipal Crisis Unit with support from the Cantonal Crisis Unit of the Canton of Valais (French acronym CERISE). Large-scale weather patterns are observed and analyzed by CERISE. In case of an approaching critical weather situation or following a meteorological warning from the Swiss national weather service, MeteoSwiss, CERISE closely analyses the weather, and if the situation deteriorates and intense precipitation is expected, they issue a storm warning. Based on the weather data and the information available on the current hazard status of the catchment, the Municipal Crisis Unit will assess the situation and decide on the measures to be taken (e.g., evacuation of buildings, closing of roads). Predefined and pre-exercised scenarios may guide the Municipal Crisis Unit in their work which is however very much situationoriented. Their success in dealing with the crisis consequently depends on the personal experience of the members and on the reliability and quality of the weather forecast, an issue addressed below.

The link between the Illgraben alarm system and the Municipal Crisis Unit is formed by the Illgraben Security Commission (including catchment observers), who operates the alarm system, performs the catchment observation, maintains the detection system, and is responsible for the information-dissemination concept. In case there is no remarkable change in the catchment, the Illgraben Security Commission runs the alarm system independently. When the geomorphologic situation in the catchment changes they ask a local geologist to evaluate the situation. If the situation is deemed hazardous, the Municipal Crisis Unit is activated.

\subsection{Debris-flow detection}

\subsubsection{General observations and setup}

The alarm system was designed to provide a rapid and reliable alert and reporting of debris-flow occurrence. The system includes redundant sensors and sends a daily email that can be used to identify if the system has malfunctioned. The alert system uses the public mobile phone network (GSM) for communication and data exchange. This system is reliable enough that it is used by many fire departments for paging emergency workers, and it has performed flawlessly since the start of our debris-flow observations in Switzerland (in 2000). To maximize the time available for response, the sensor system was installed as far upstream as possible yet within range of the GSM network, at a location where all debris flows pass (at check dams 9 and 10, see Fig. 2). An additional detection point is located on the upstream-most check dam (check dam 1), but this location is less reliable 
due to the short duration of direct sunlight for the solar panel which charges the batteries, weaker GSM signal, and rockfall hazard.

\subsubsection{Detection sensors}

Experience with debris-flow detection sensors has been acquired by the WSL through the installation and maintenance of four debris-flow observation stations (e.g., Hürlimann et al. 2003). Since 2000 we have successfully collected data from more than 30 debris flows or hyper-concentrated flows as well as normal floods at the Illgraben. The distinction between debris flow and hyperconcentrated flow is gradational, with debris flows having a larger (measured) bulk density and little or no water visible at the flow front (e.g., McArdell et al. 2007). Both flow types may have a sediment-rich front with boulders as large as or larger than the flow depth, and both may travel at up to several meters per second and therefore are equally dangerous, so both are considered in our system. Although other sensors are available, we have extensive experience with ground movement sensors (geophones) and flow depth sensors (e.g., ultrasonic and radar sensors) which have been demonstrated to be reliable at the Illgraben. Both have been frequently used at other debris-flow observation stations as well (Arattano 1999; Genevois et al. 2000; Itakura et al. 2005; Marchi et al. 2002), and both have been installed here as described below.

The warning system is completely independent of the existing debris-flow observation station due to differences in the ownership and objectives (e.g. the warning system must be reliable and robust and the observation station has to be more precise and often new sensor technologies are tested there). We installed geophones (Geospace Technologies, model GS-20DX) bolted to the concrete at check dams 1, 9, and 10. The check dams (see Fig. 3 for a typical example) are always in contact with the flow because the flow accelerates as it passes over the brink, hindering deposition unless the check dam is buried due to sedimentation, for example during backwater effects originating from downstream. For this reason, the arrival of a debris flow can be accurately determined as the boulders at the flow front roll or slide over the check dam and activate the geophones. The analog signal from the geophone is digitized at the geophone for filtering and to reduce the data volume. The number of impulses per second and their duration is extracted from the analog signal, with an impulse defined here as the output voltage exceeding an empirically determined threshold. The sensor system at check dam 1 (Fig. 2) sends a first alarm and activates the flashing alert lights and acoustic signals on the fan area downstream. In case a flow is not detected at check dam 1, a first alarm can also be issued from check dams 9 or 10 if the sensor thresholds are exceeded. The initial alarm duration was initially set to $20 \mathrm{~min}$, corresponding to the expected travel time of a typical debris flow from the detection point to the end of the channel at the Rhone River. During an alarm, the sensor status is checked every $5 \mathrm{~min}$; without a confirmation of the alarm from the sensor system at check dams 9 and 10 (or check dam 1), the alerting devices are deactivated after $10 \mathrm{~min}$ of belowthreshold sensor values. This could happen in case of false alarms caused by ground vibrations due to thunderstorms, earthquakes, rockfall, and similar processes.

Three instruments for measuring flow depth, ultrasonic, laser, and radar distancemeasuring devices have been tested at our observation stations. Ultrasonic sensors are troublesome because under conditions of rapidly changing flow depth and splashing on the surface of the flow they sometimes do not return a signal (Hürlimann et al. 2003). Laser sensors provide high-quality data for debris flows (e.g., McArdell et al. 2007), but do not provide a useable signal for flood or hyper-concentrated flows. Radar sensors have a builtin smoothing algorithm that provides a stable signal under conditions of rapidly changing 
flow depth or splashing on the surface of the flow, but the signal is delayed by a few seconds and changes in surface elevation are smoothed in comparison with laser sensors, making them somewhat less useful for research but reliable for warning. Therefore, we decided to use radar sensors for this project. In general, we install them just upstream of the crest of a check dam because the bed elevation does not change significantly during a debris flow, as discussed above, thereby avoiding inaccuracies in determining flow depth arising from basal erosion or deposition. For the debris-flow detection system we installed two radar sensors (Vega, model Vegapuls 68) at the same cross section (check dam 10, see Fig. 2). The two-sensor arrangement (Fig. 5) is intended to minimize problems related to the fact that individual large boulders sometimes become temporarily lodged just upstream of the crest of a check dam during periods of decreasing flow surface elevation; smaller but still hazardous flows may travel around rather than over the boulders.

In practice, a debris flow is detected if the geophone signal indicates more than a predefined number of impulses in each second for more than $5 \mathrm{~s}$, and/or the flow depth exceeds a predefined increase in height for more than $5 \mathrm{~s}$, so the shortest possible detection-to-alert time is $5 \mathrm{~s}$ (and additionally a few to a few tens of seconds for transmission). When the thresholds are exceeded, the detection installations send signals to the event-evaluation processing unit, installed at the community offices, which in turn

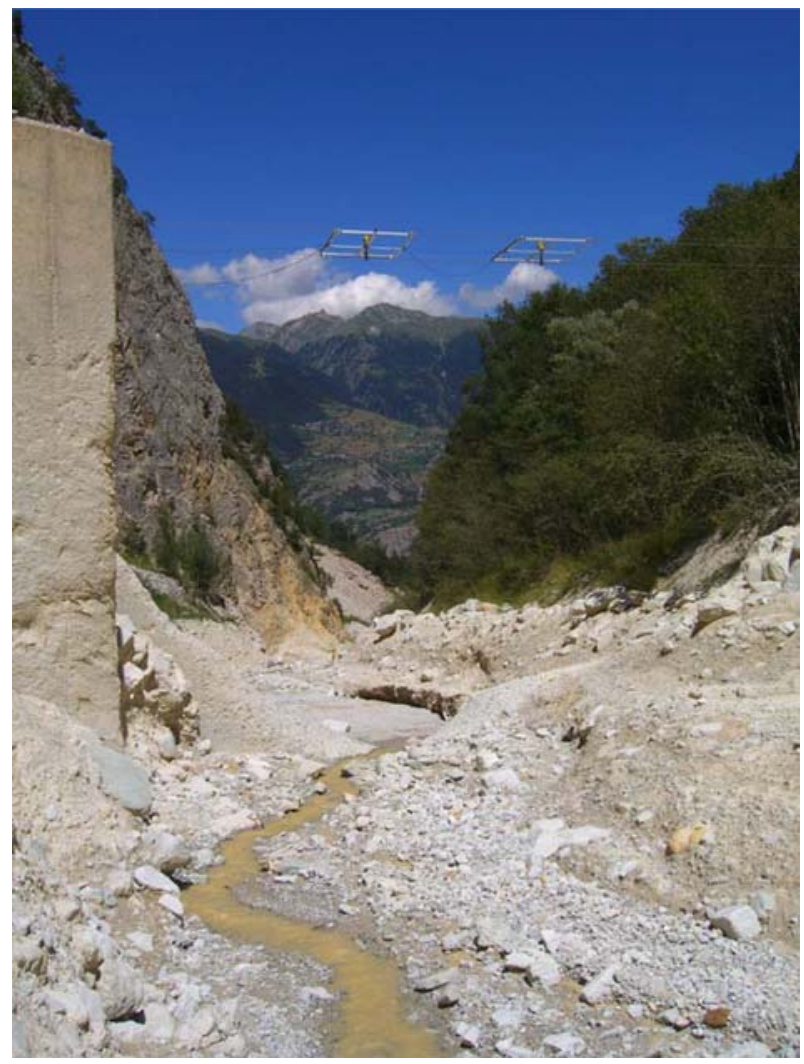

Fig. 5 The two radar sensors at check dam 10 (Fig. 2) that measure flow depth as part of the detection system (downstream view) 
activates the lights and alert sirens and sends text messages, emails, or pager signals to the decision makers in the community. If one of the sensors in the detection system registers signals outside the plausible predefined limits, that information is also sent to the municipal crisis unit manager. In the absence of the daily status email, it can be assumed that the station should be inspected and repaired and that observers should be sent into the field in critical weather situations.

\subsection{Catchment observation}

The main goal of the third module in the alarm system, catchment observation, is to identify new hazardous conditions that could lead to unusually large debris flows or to flows that are capable of leaving the channel near populated areas. To facilitate these observations, the catchment was divided into three sectors: the catchment upstream and upslope of check dam 1 (observation sector 3 on Fig. 2), the channel corridor between the fan apex and the uppermost check dam (check dam 1 on Fig. 2; sector 2), and the channel on the debris fan downstream of the apex (observation sector 1 on Fig. 2). This spatial division allows for an efficient evaluation of the current state of the entire catchment and is safe for the observers because the lower catchment (sectors 1 and 2) is easily accessible and most of the upper catchment (sector 3) can be seen from one of several lookout points (Fig. 2).

The Illgraben is an exceptionally active catchment and there are many processes that could lead to a considerable change in the potential for damage-causing debris flows. The discharge-carrying capacity of the channel on the debris fan itself (sector 1, Fig. 2) is variable in space and time. The difference between the top of the bank and channel bed largely determines the discharge capacity along the channel at any given time. Some channel reaches downstream of the fan apex have a mean slope angle of only $6^{\circ}(10 \%)$, and it is possible that these areas could become the depositional sites and thereby decrease the local capacity of the channel (as was observed in 1995), making it more likely that subsequent flows could leave the channel and flow into adjacent inhabited areas. In some places the channel banks are relatively narrow and could be undermined by toe erosion during streamflow, leading to bank failure and breaching. Landslides have the potential to block the channel which may create temporary reservoirs which may fail and generate large debris flows (sectors 2 and 3, Fig. 2). Such a scenario probably led to a very large debris-flow event on June 6, 1961 (Figs. 4a, b). Earlier that year a large rock avalanche with a volume of $3-5 \times 10^{6} \mathrm{~m}^{3}$ occurred in the upper catchment and blocked the torrent channel (Hürlimann et al. 2003). In 2001 a rock avalanche with a volume on the order of $100,000 \mathrm{~m}^{3}$ created a small lake which was mostly filled with sediment and did not catastrophically fail. It is also conceivable that large landslides, especially in the steep sediment-filled torrents draining the north face of the Illhorn, could be generated during an unusually large rainfall event and mobilize directly into a debris flow, or could be mobilized by torrential flooding and transform into a debris flow. Therefore, the general degree of sediment availability in torrential side channels (sector 3 ) is also of interest and is observed. The infilling of these torrent channels with sediment and their subsequent flushing is currently being addressed as part of an independent research project.

In all the three observation sectors, the site assessment is carried out by trained observers from the community using a form that is completed in the field and later entered into the IFKIS-Hydro database that is designed to assist data transfer in the case of storm or other crisis events (Romang et al. 2007; Rhyner and Hegg 2006), ensuring that the data are always available to the local project manager. Site observations are carried out monthly 
along the channel reaches (sectors 1 and 2) and fortnightly from the lookout points (sector 3 ). In addition, observations are scheduled after every debris flow detected by the alarm system.

\subsection{Potential application of precipitation forecasts}

Meteorological forecasts allow for a significant increase of advance warning time but constitute one of the most challenging elements in the entire warning system concept. Forecasts must provide sufficiently detailed spatial and temporal resolution, and quantitative correlations between measurable meteorological parameters and the forecast has to be established.

Meteorological precipitation can be divided into front-type and thunderstorm-type events. Front-type events, due to the relative spatial homogeneity, allow for local forecasts up to several days in advance. In contrast, thunderstorm forecasts are considerably more difficult, especially over complex mountainous topography and are presently possible for approximately $1 \mathrm{~h}$ before an event. MeteoSwiss regularly issues thunderstorm warnings; the WSL provides feedback on forecast versus observed storms, which in the long term may assist them in improving the reliability of thunderstorm forecasting models. Until more accurate long-term thunderstorm forecasts become available, improvements can be achieved by both the development of empirical thresholds with a systematic comparison between the observed and the forecasted evolution of the precipitation and by improved local radar coverage so that decision makers can better track storm cells and compare forecast information. Unfortunately radar coverage in the Illgraben region is not yet optimal because the resolution is coarse (Litschi 2005). However a new research radar installation in the region is soon expected to become operational and may increase the coverage of the region and therefore the accuracy of thunderstorm forecasts.

The correlation between the properties of rainfall and debris-flow initiation has been clearly identified both at a local scale (e.g., Deganutti et al. 2000; Berti and Simoni 2005) and at a global scale (e.g., Caine 1980; Innes 1983) and is often parameterized using rainfall intensity and duration. A comprehensive summary and comparison of rainfall thresholds and their range of applicability, stratified by region and event type (e.g., shallow landslide, debris flow, etc.) is available in Guzzetti et al. (2007, 2008). Based on the available precipitation records from 1996 to 2000 at the Acquabona catchment, Berti and Simoni (2005) present a rainfall duration-intensity chart subdivided into several domains. Each storm event is classified in terms of hydrologic response in the debris-flow initiation area: (i) no catchment response, (ii) fast subsurface stormflow, and (iii) debris-flow triggering after surface runoff occurrence. Furthermore, two threshold lines are illustrated separating the rainfall events that produced similar response.

For the Acquabona catchment, this separation is very distinct because only very intense, typically short rainstorms lead to hydrologic conditions eventually leading to surface runoff formation and debris flows. Above the rainfall intensity-duration debris-flow threshold line, only storms that have caused debris flows have been observed between years 1996 and 2000. This situation is particularly favorable for hazard forecasting and warning because it potentially enables procedures with short advance warning times, and yet high reliability (low false alarm ratio). However, these results must be extensively tested under other hydrological and geological conditions before they can generally be applied to other catchments.

Unfortunately, many alpine torrents such as the Illgraben and the Moscardo (Deganutti et al. 2000) have more spatial variability and the response to rainfall is therefore less 
unique than at the Acquabona catchment. Perhaps individual sub-basins respond in a predictable way but the net result is more complex; in any case the density of rain gauges at the Illgraben is insufficient to explore this possibility. Although intensive storms of short duration are likely to trigger a debris flow, this is not always the case (McArdell and Badoux 2007). During the snowmelt season (e.g., through June) large amounts of soil moisture are present, so a relatively small rainfall event may initiate a debris flow. Even though rain gauge 1 (Fig. 2) is located near the main initiation area, only $\sim 50 \%$ of the rainfall events exceeding the empirical duration-intensity threshold cause debris flows that reach the populated areas indicating that other factors such as antecedent soil moisture, sediment availability, local topography, soil development and initiation process type (e.g., Godt and Coe 2007; Gregoretti and Dalla Fontana 2008) may also be important. In the Moscardo catchment, for 9 years of rainfall data and 15 debris flows, Deganutti et al. (2000) found that only $\sim 35 \%$ of rainfall events exceeding the rainfall intensity-duration threshold actually produced a debris flow that reached the basin outlet. However, at the Moscardo the rainfall data are only reported for 60-min intervals, which may not adequately reflect very intense but short-duration rainfall events that may trigger debris flows. The implications of these observations for warning include the increase in the chance of false alarms and a subsequent desensitizing of the community to the problem, thereby impeding the benefits of a warning system based solely on meteorological forecast and rainfall threshold data.

If sufficient resources are available, one comprehensive warning option would be to combine local (e.g., Illgraben) threshold curves along with local radar-supported precipitation model forecasts to both extend the advance warning time and the reliability of debris-flow forecasts, similar to what has been proposed in Southern California (NOAAUSGS Debris Flow Task Force 2005). Because of the large initial investment, such a system may only be economically viable if the forecasts can be widely applied to other hazardous situations in the region covered by the radar.

\section{Discussion}

\subsection{Performance of the detection network}

Due to the rapid travel time and high frequency of events, our initial focus was to minimize the delay between detection and alerting while ensuring a very low proportion of false alarms. The alert system was installed at the beginning of the 2007 flow season and issued 20 alarms. In this paper we analyze only the hazardous events (Table 1) as described below. A comparison with the separate Illgraben research observation station (discussed earlier) provides an opportunity to evaluate the performance of the detection network and the results may be of interest to others designing similar systems. The main practical goal of this evaluation is to provide a basis for the optimization of the system: to reduce the proportion of unnecessary alarms while still detecting every hazardous event. Because no large debris flows (e.g., flows that overtopped the channel banks) were observed, the discussion here will focus on the detection system and a more comprehensive evaluation of the entire system, including the catchment observation, will be made after sufficient experience has been gained.

Overall the detection system performed satisfactorily, detecting every debris flow and all large flood flows that reached the detection point (Fig. 2). With only one exception, a false alarm triggered by the geophone at check dam 1 (perhaps caused by rockfall), the 


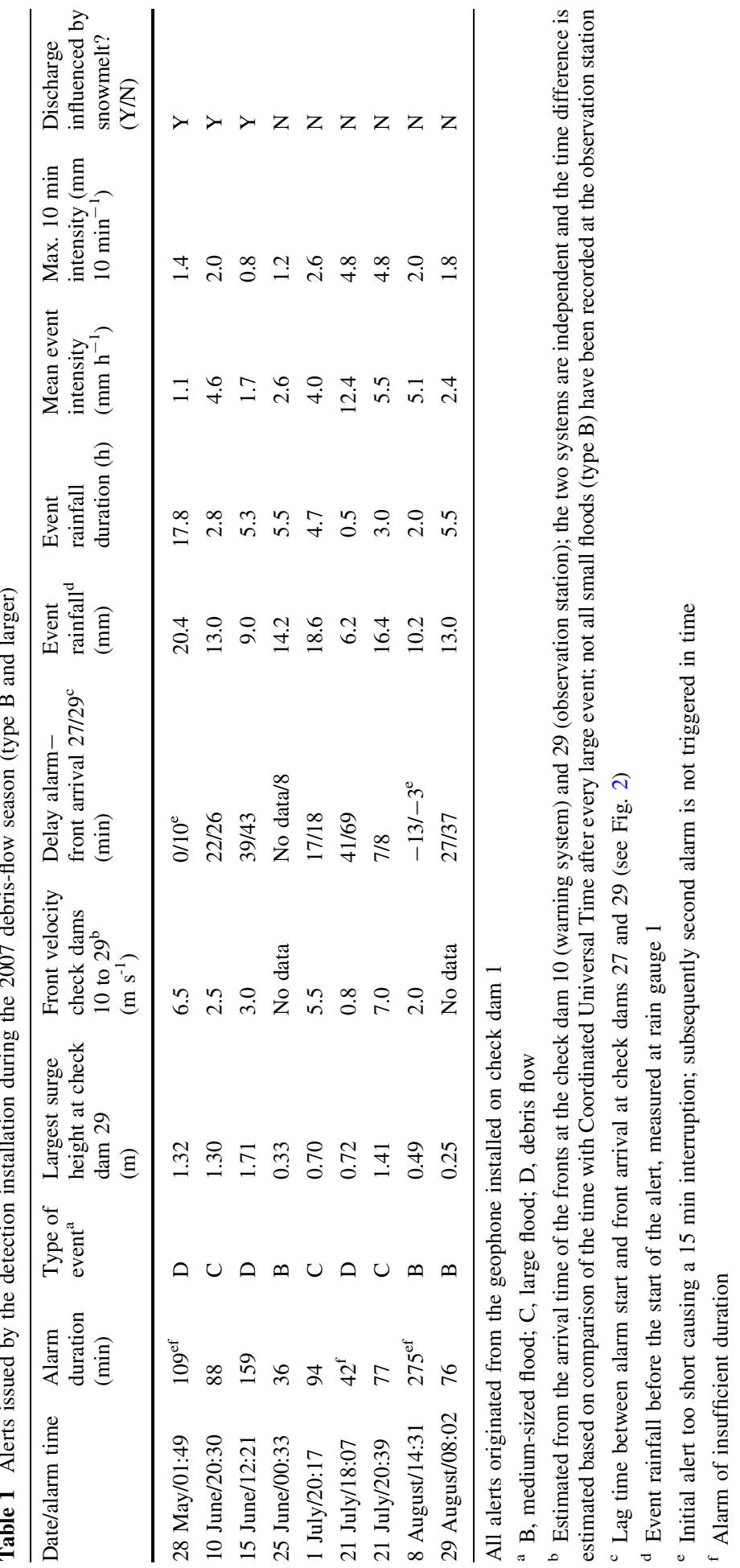


detection system consistently indicated a rising stage. Ten of the events were quite small (type A floods, defined as events with a flow depth less than approximately $0.25-0.3 \mathrm{~m}$ ) which do not constitute a significant hazard, indicating that the detection thresholds should be adjusted to minimize unnecessary alarms. However, the detection of such events is not considered to be a major problem which could de-sensitize the local population to the alarms, as could occur in the case of many false alarms. While type A floods are hazardous for children, the organizational protection measures (described earlier) include education in the schools to sensitize children about the dangers involved in entering the channel.

The flow depth boundary between type A and larger events (listed in Table 1) can be interpreted in terms of the likelihood of a person being able to safely wade across the channel when water is flowing. Laboratory experiments indicate that humans of a variety of different weights and heights are capable of wading in rivers if the product of velocity (in $\mathrm{m} \mathrm{s}^{-1}$ ) and flow depth (in $\mathrm{m}$ ) is less than approximately $1 \mathrm{~m}^{2} \mathrm{~s}^{-1}$ (Abt et al. 1989). Our estimate based on the back-calculated Manning's $n$ value for a large flood at the Illgraben (Manning $n=0.07$ ) and the mean channel slope of the channel on the fan (slope $=0.1$ ) indicates that the maximum wadable depth is on the order of $h=0.4 \mathrm{~m}$. However, the subjects in the aforementioned experiments were adults and their perception of safety was probably enhanced by the presence of security ropes, so our value of $h \sim 0.25-0.3 \mathrm{~m}$ is reasonable given the uncertainties in the properties of the flow and the topographic variation in flow depth at a channel crossing.

The remaining nine alerts were all initiated by events capable of endangering the life of a person in the channel: three debris flows (type D), three large flood or hyperconcentrated flows (type C), and three medium-sized floods (type B). In six of the nine hazardous events the timing of the alarm was satisfactory (see Sect. 4.3): the flashing-light signal started at all three alert points at least several minutes before the arrival of the debris flow front or before the rapid stage increase during floods observed at check dam 27 (where we have data from the independent observation station). The remaining three alarms were of insufficient duration: the alarm turned off too early, meaning that there is a chance that the alert light would stop before the arrival of a flow front at the downstream end of the channel (Table 1). Unfortunately, we do not have independent data for the upstream-most alert station (Pletschen, see Fig. 2), and given the expected spatial changes in velocity as the channel geometry varies, it is difficult to independently and accurately estimate the arrival time of fronts at this location.

The three cases with insufficient alarm duration generally reflect the complexity of natural events. In the case of slow, granular debris flow (Table 1: July 21, 2007 first surge; Fig. 6), the alarm turned off before the surge arrived at the downstream end of the channel because the surge was much slower than expected in the initial design. Multi-surge events are also common: when the first surge is a debris flow, the likelihood of a person attempting to cross the channel bed by foot or on horseback after the alarm has switchedoff is low due to the significant accumulations of partially fluidized muddy sediment on the channel bed and banks (e.g., July 21, second surge; Fig. 6). The problem is perhaps most acute when the first surge is a relatively small flood which leaves no significant muddy deposits in the channel and the second surge is a substantially larger flow (e.g., May 28): a person may be tempted to cross the channel after the alert lights stop flashing following the first flood but before the larger surge arrives. In general such cases can be readily solved, for example, simply by extending the duration of the alarm or by installing additional detection stations further downstream. 


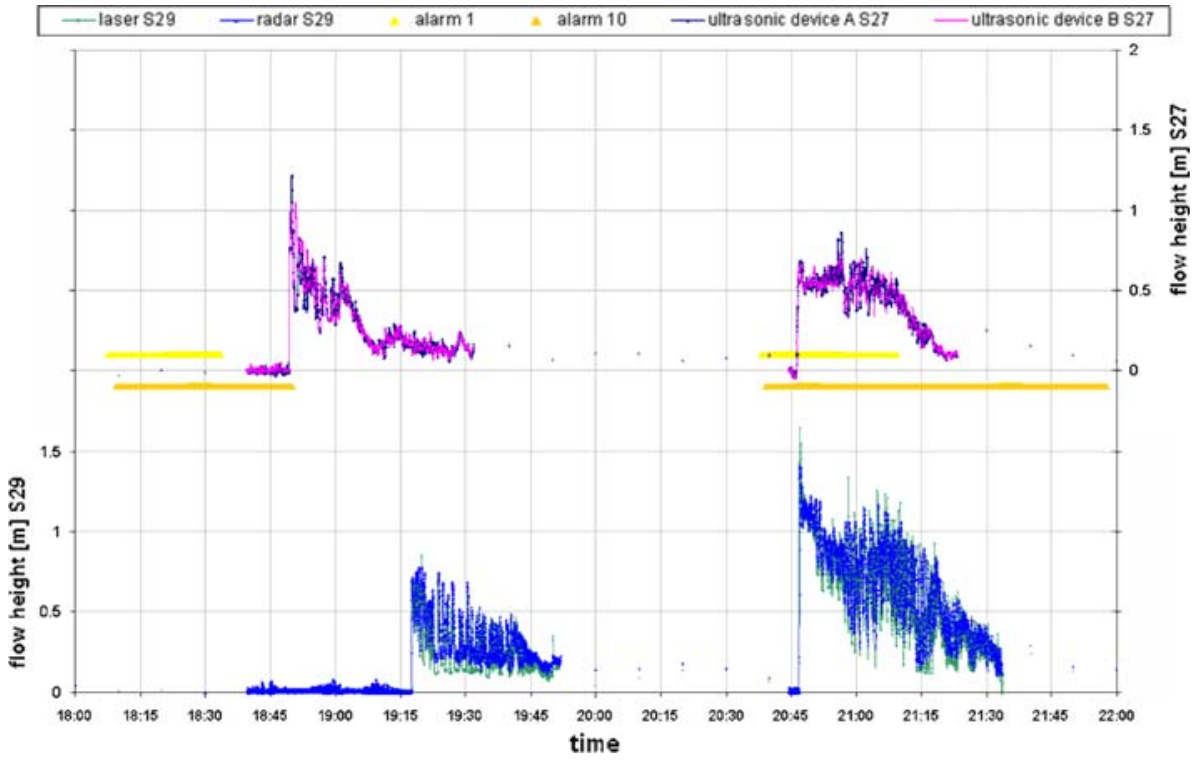

Fig. 6 Comparison of detection system alarm and separate debris flow observation station data illustrating successful and inadequate alarms from July 21, 2007. The data from check dam 27 (upper curve) and check dam 29 (lower curve) illustrate a debris flow event followed by a large flash flood event. The yellow and orange lines (alarms from check dams 1 and 10, respectively) indicate when the alarm signals were operating

\subsection{Comparison with rainfall data}

In a separate analysis of debris-flow activity and rainfall data from rain gauge 1 (Fig. 2) situated several hundred meters from the initiation zone, a rainfall intensity-duration threshold was identified, above which debris flows may be expected and below which debris flows have not been observed (McArdell and Badoux 2007): $I_{\mathrm{d} f}=5.4 D_{\mathrm{d} f}{ }^{-0.79}$, where $I_{\mathrm{d} f}=$ mean rainfall intensity ( $\mathrm{mm} /$ hour) until a debris flow is triggered, and $D_{\mathrm{d} f}=$ rainfall duration (hours) until a debris flow is triggered. This relationship was observed for $0.3<D_{\mathrm{d} f}<21 \mathrm{~h}$. To this end, 10-min rainfall data were summed (until the independent debris-flow observation station detected a debris flow) to establish the event precipitation $P_{\mathrm{E}}$. Note that $P_{\mathrm{E}}$ is preceded by $6 \mathrm{~h}$ without more than a trace (one $0.1 \mathrm{~mm}$ signal) of rainfall.

A comparison of that threshold and the rainfall data for 2007 (Fig. 7) indicates that all hazardous events (e.g., event types B, C, and D described above) lie above the threshold line. Additionally, most of the non-hazardous (type A) events also plot above the threshold. In the three cases where one rain storm (by this definition) produced more than one alarm, the second alert is considered herein to have "inherited" precipitation from the previous alert. These second alerts are all type A events and are depicted (Fig. 7) as surrounded by a square. The Illgraben may be a special case because sediment delivery from the catchment appears to be limited by the availability of water rather than sediment (Schlunegger et al. in press). However, in one case a debris flow triggered by a storm that lies just above the threshold (June 15, 2007) was followed 10 days later by a larger storm which resulted in only a large flood (type B) event, suggesting that the source area may have been depleted 


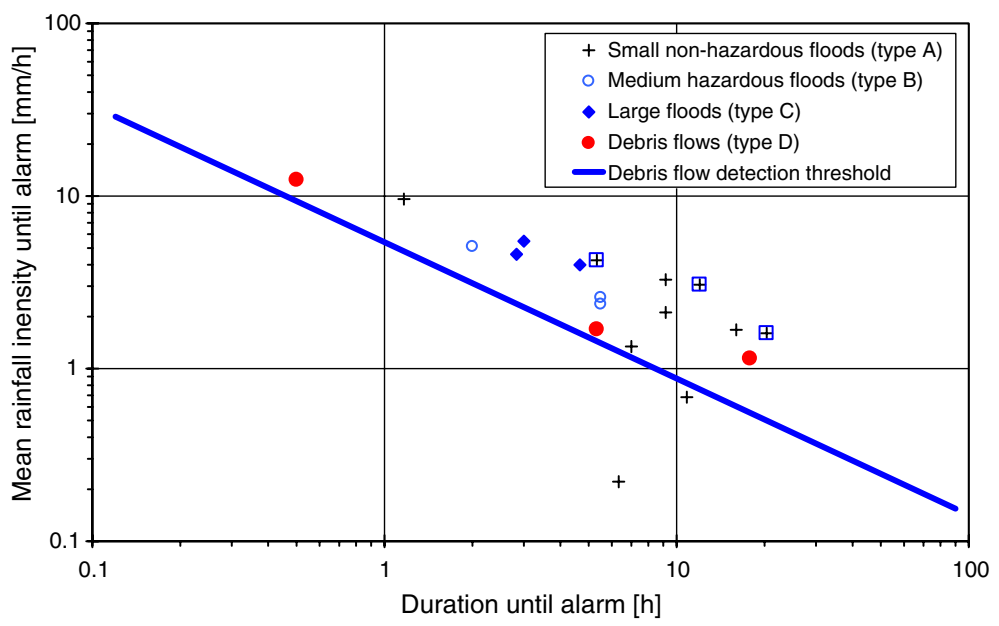

Fig. 7 Relationship between rainfall duration and average intensity for the Illgraben catchment as established by McArdell and Badoux (2007) and location of data from the 2007 debris-flow and flood events. All type B, C and D events (hazardous events) listed in Table 1 lie above the threshold line. Additionally, most of the non-hazardous (type A) events also plot above the threshold. Three type A events are enclosed by a square symbol, indicating inherited rainfall as described in Sect. 5.2

of sediment. Unfortunately, this hypothesis is not yet testable because the Illgraben has at least three distinct initiation areas, and we cannot determine which source area or areas were activated by these storm events. A few more years of data will be necessary before the rainfall threshold curve can be considered to be a reliable predictive tool. If validated for warning, the information from a rain gauge (within the catchment) could be integrated into the warning system, and forecasts of rainfall intensity could be used for planning purposes (e.g., evacuation plans) in a hazardous case such as a rainstorm approaching the catchment shortly after the formation of a large landslide-dammed lake in the initiation zone. Two major concerns for applying rainfall-duration thresholds in Alpine catchments are the presence of snowmelt which may produce saturated soils which may fail at subthreshold rainfall conditions, and the elevation of the rain gauge in the source area when the temperature is close to zero which may result in recording no rainfall (e.g., snow) when at lower elevations in the source area the rainfall may be sufficient to trigger an event. Snowmelt was a factor in one-third of the events in 2007 (Table 1).

\subsection{System integration}

Perhaps the main problem with the overall alarm concept is that the modules are not yet fully integrated into a self-sustaining system capable of being operated by non-researchers: many research questions and practical issues need to be solved beforehand. Rainfall forecasting (module 4), for example, especially in the case of a new hazardous situation in the upper catchment such as a new landslide blocking the main channel, is a current research topic. The reaction time of people in or near the channel is assumed to be short enough that they can leave the endangered area after an alert is issued; the reaction time of the community crisis center following a warning is yet to be investigated.

Another problem is how to objectively integrate the observer data into the decisionmaking process. At a minimum the observer network concept has sensitized authorities 
about the importance of geomorphic processes in the upper catchment that could influence the potential for an increase in the likelihood of a large debris flow. Changes in the elevation of the channel on the fan also influence the potential for overbank flow; however, there is not yet a method that can be used to relate observations of channel bed to the potential for overbank flow at the Illgraben. It is therefore important that the current state of awareness be maintained, especially through staffing changes in the community crisis center, and that the system remains flexible enough so that new process knowledge can be incorporated into the decision-making processes.

Finally, our understanding of the debris-flow processes remains incomplete. Until now very large debris flows have only been observed in the case of dam-break initiation. It is possible that extremely large events could also be generated under other conditions, such as an unusually large frontal storm during the snow-melt season, or the mobilization of an exceptionally large landslide in the upper catchment. At the moment such not-yet observed processes have to be considered as a residual risk.

\section{Conclusions and outlook}

A warning system for debris flows and large flood flows (in many cases flash floods with large front velocities) was designed and implemented at the Illgraben catchment and consists of modules for organizational measures in the community, event detection and alerting, geomorphic catchment observation, and weather forecasting. This system provides automated alert signals near the active channel just before (5-15 min) the arrival of a hazardous event at the uppermost frequently used channel crossing, and it is intended to provide support in the event of large debris flows that are capable of leaving the channel and reaching populated areas.

After the first year of operation, it was possible to evaluate the performance of the debris-flow detection module, which provides alerting in the form of flashing lights and sirens at channel crossings where pedestrians may attempt to cross the channel. The results indicate that the detection and alert part of the system functions well, with 20 automated alarms at all major footpaths crossing the channel bed for three debris flows, three large floods, three medium-sized (hazardous) floods, and 10 small floods. Only one false alarm (e.g., no increase in stage was observed following the alarm) was issued. The major difficulty encountered is related to the large degree of variability and complexity of the events, which will be largely solved by increasing the duration of the alarm. In comparison with rainfall data, all the alarms for hazardous events (flows with a depth larger than $\sim 0.25-0.3 \mathrm{~m}$ ) were produced by storms with a duration and intensity larger than the initiation threshold for debris-flow activity that was defined in an earlier study at the Illgraben (McArdell and Badoux 2007).

Large debris flows that leave the channel are only expected in the case of the rapid emptying of new landslide-generated lakes in the upper catchment or in the case of a failed or breached levee or reduced channel conveyance capacity in the channel on the populated debris fan. Observers have been trained to identify such changes, but no unusual activity was observed in the first year of operation. The comparison of the alarm data with the rainfall information suggests that the rainfall forecasts could be used to provide some degree of pre-rainfall warning to evacuate people in the hazard zone in the event of a new hazardous situation such as the formation of a large valley-blocking landslide in the debrisflow initiation area, as was observed in 1961. Additional applied research and data on 
weather forecasting, including summer thunderstorms, and rainfall thresholds for debrisflow initiation are necessary.

The experiences gained at the Illgraben catchment also support a larger applied research program in Switzerland for natural hazards, IFKIS-Hydro (Romang et al. 2007), which provides real-time observation data for hazard-crisis managers during storm events to support their decisions.

Acknowledgments The work presented here was coordinated within the framework of the project HYDRALP and is a contribution to EU-Project IRASMOS. We are very grateful to D. Bérod (DSFB/SRCE, Canton of Valais), C. Wuilloud, (DWL/SFP, Canton of Valais), and the municipality of Leuk for their support of this study. We greatly appreciate the project support of Ph. Teysseire and F. Dufour and assistance of B. Fritschi in the design and installation of the detection system. Two anonymous reviewers provided helpful comments that have improved the manuscript.

\section{References}

Abt SR, Wittler RJ, Taylor A, Love DJ (1989) Human stability in a high flood hazard zone. Water Resour Bull 25(4):881-890

Aleotti P (2004) A warning system for rainfall-induced shallow failures. Eng Geol 73(3-4):247-265. doi: 10.1016/j.enggeo.2004.01.007

Arattano M (1999) On the use of seismic detectors as monitoring and warning systems for debris flows. Nat Hazards 20(2-3):197-213. doi:10.1023/A:1008061916445

Bacchini M, Zannoni A (2003) Relations between rainfall and triggering of debris-flow: case study of Cancia (Dolomites, Northeastern Italy). Nat Hazards Earth Syst Sci 3:71-79

Berti M, Simoni A (2005) Experimental evidences and numerical modelling of debris flow initiated by channel runoff. Landslides 2:171-182. doi:10.1007/s10346-005-0062-4

Brand EW, Premchitt J, Phillipson HB (1984) Relationship between rainfall and landslides in Hong Kong. Proceedings of 4th international symposium on landslides, Canadian Geotechnical Society, Toronto, pp 377-384

Bründl M, Etter HJ, Steiniger M, Klingler C, Rhyner J, Amman WJ (2004) IFKIS—a basis for managing avalanche risk in settlements and on roads in Switzerland. Nat Hazards Earth Syst Sci 4:309-313

Caine N (1980) The rainfall intensity - duration control of shallow landslides and debris flows. Geogr Ann 62 A:23-27

Cannon SH, Ellen SD (1985) Rainfall conditions for abundant debris avalanches, San Francisco Bay region, California. Calif Geol 38:267-272

Chan RKS, Pun WK (2004) Landslip warning system in Hong Kong. Geotech News 22(4):33-34

Chang SY (2003) Evaluation of a system for detecting debris flows and warning road traffic at bridges susceptible to debris flow hazard. In: Rickenmann D, Chen CL (eds) Debris-flow hazards mitigation: mechanics prediction, and assessment. Millpress, Rotterdam, pp 731-742

Chen C-Y, Chen T-C, Yu F-C, Yu W-H, Tseng C-C (2005) Rainfall duration and debris-flow initiated studies for real-time monitoring. Environ Geol 47:715-724. doi:10.1007/s00254-004-1203-0

Costa JE (1984) Physical geomorphology of debris flows. In: Costa JE, Fleisher PJ (eds) Developments and applications in geomorphology. Springer, New York, pp 268-317

Decker R, Jensen N, Rice R (1997) Automated snow avalanche hazard reduction. In: Chen CL (ed) Debrisflow hazards mitigation: mechanics, prediction, and assessment. American Society of Civil Engineers (ASCE), San Francisco/New York, pp 530-539

Deganutti AM, Marchi L, Arattano M (2000) Rainfall and debris-flow occurrence in the Moscardo basin (Italian Alps). In: Wieczorek GF, Naeser ND (eds) Debris-flow hazards mitigation: mechanics, prediction, and assessment. A.A. Balkema, Rotterdam, pp 67-72

Fan J-C, Liu C-H, Wu M-F, Yu SK (2003) Determination of critical rainfall thresholds for debris-flow occurrence in central Taiwan and their revision after the 1999 Chi-Chi great earthquake. In: Rickenmann D, Chen CL (eds) Debris-flow hazards mitigation: mechanics, prediction, and assessment. Millpress, Rotterdam, pp 103-114

Genevois R, Tecca PR, Berti M, Simoni A (2000) Debris-flows in the Dolomites: experimental data from a monitoring system. In: Wieczorek GF, Naeser ND (eds) Debris-flow hazards mitigation: mechanics, prediction, and assessment. A.A. Balkema, Rotterdam, pp 283-291

Godt JW, Coe JA (2007) Alpine debris flows triggered by a 28 July 1999 thunderstorm in the central Front Range, Colorado. Geomorphology 84:80-97. doi:10.1016/j.geomorph.2006.07.009 
Graf C, Badoux A, Dufour F, Fritschi B, McArdell BM, Rhyner J, Kuntner R, Teysseire P, Nigg U (2007) Alarmsystem für murgangfähige Wildbäche-Beispiel Illgraben. Wasser Energ Luft 99(2):119-128

Gregoretti C, Dalla Fontana G (2007) Rainfall threshold for the initiation of debris flows by channel-bed failure in the Dolomites. In: Chen CL, Major JJ (eds) Debris-flow hazards mitigation: mechanics, prediction, and assessment. Millpress, Rotterdam, pp 11-22

Gregoretti C, Dalla Fontana G (2008) The triggering of debris flow due to channel-bed failure in some alpine headwater basins of the Dolomites: analyses of critical runoff. Hydrol Process 22(13):2248-2263. doi: 10.1002/hyp.6821

Gubler H (1996) Remote avalanche warning, alarm and control systems. Fundamentals, applications and experience. In: Proceedings of the international snow science workshop, Banff, Alberta, Canada, 6-10 October 1996, pp 165-172

Guzzetti F, Peruccacci S, Rossi M, Stark CP (2007) Rainfall thresholds for the initiation of landslides in central and southern Europe. Meteorol Atmos Phys 98(3-4):239-267. doi:10.1007/s00703-007-0262-7

Guzzetti F, Peruccacci S, Rossi M, Stark CP (2008) The rainfall intensity-duration control of shallow landslides and debris flows: an update. Landslides 5:3-17. doi:10.1007/s10346-007-0112-1

Hirano M (1997) Prediction of debris flow for warning and evacuation. In: Armanini A, Michiue M (eds) Recent developments on debris flows. Springer, Berlin, pp 7-26

Hürlimann M, Rickenmann D, Graf C (2003) Field and monitoring data of debris-flow events in the Swiss Alps. Can Geotech J 40:161-175. doi:10.1139/T02-087

Innes JL (1983) Debris flows. Prog Phys Geogr 7:469-501. doi:10.1177/030913338300700401

Itakura Y, Koga Y, Takahama J, Nowa Y (1997) Acoustic detection sensor for debris flow. In: Chen CL (ed) Debris-flow hazards mitigation: mechanics, prediction, and assessment. American Society of Civil Engineers (ASCE), San Francisco/New York, pp 747-756

Itakura Y, Inaba H, Sawada T (2005) A debris-flow monitoring devices and methods bibliography. Nat Hazards Earth Syst Sci 5:971-977

Iverson RM, Vallance JW (2001) New views of granular mass flow. Geology 29:115-118. doi: 10.1130/0091-7613(2001)029\&lt;0115:NVOGMF\&gt;2.0.CO;2

Jakob M, Holm K, Lange O, Schwab JW (2006) Hydrometeorological thresholds for landslide initiation and forest operation shutdowns on the north coast of British Columbia. Landslides 3(3):228-238. doi: 10.1007/s10346-006-0044-1

Keefer DK, Wilson RC, Mark RK, Brabb EE, Brown WM, Ellen SD, Harp EL, Wieczorek GF, Alger CS, Zatkin RS (1987) Real-time landslide warning during heavy rainfall. Science 238:921-925. doi: 10.1126/science.238.4829.921

Kung H-Y, Ku H-H, Wu C-I, Lin C-Y (2008) Intelligent and situation-aware pervasive system to support debris-flow disaster prediction and alerting in Taiwan. J Netw Comput Appl 31(1):1-18. doi:10.1016/ j.jnca.2006.06.008

Litschi M (2005) Kombination von Radar- und Pluviometerdaten zu stündlichen Niederschlagsfeldern für die Schweiz: Validierung und klimatologische Auswertung. Diploma thesis, Swiss Federal Institute of Technology, Zurich (ETHZ). http://www.iac.ethz.ch/doc/publications/litschi_diplomathesis_2005.pdf. Cited 31 Jan 2008 (in German with English abstract)

Liu KF, Chen SC (2003) Integrated debris-flow monitoring system and virtual center. In: Rickenmann D, Chen CL (eds) Debris-flow hazards mitigation: mechanics, prediction, and assessment. Millpress, Rotterdam, pp 767-774

Marchi L, Arattano M, Deganutti AM (2002) Ten years of debris-flow monitoring in the Moscardo Torrent (Italian Alps). Geomorphology 46:1-17. doi:10.1016/S0169-555X(01)00162-3

McArdell BW, Badoux A (2007) Influence of rainfall on the initiation of debris flows at the Illgraben catchment, canton of Valais, Switzerland. Geophys Res Abstr 9:08804

McArdell BW, Bartelt P, Kowalski J (2007) Field observations of basal forces and fluid pore pressure in a debris flow. Geophys Res Lett 34(L07406). doi:10.1029/2006GL029183

McClung D, Schaerer P (1993) Avalanche handbook. The Mountaineers, Seattle, WA

Naef D, Rickenmann D, Rutschmann P, McArdell BW (2006) Comparison of flow resistance relations for debris flows using a one-dimensional finite element simulation model. Nat Hazards Earth Syst Sci 6(1):155-165

NOAA-USGS Debris Flow Task Force (2005) NOAA-USGS debris-flow warning system-final report. US Geological Survey Circular 1283, 47 pp

Pierson TC (1986) Flow behaviour of channelized debris flows, Mount St. Helens, Washington. In: Abrahams AD (ed) Hillslope processes. Allen \& Unwin, Boston, pp 269-296

Rhyner J, Hegg C (2006) Warning systems for hydrological hazards in small catchments. In: Proceedings of the international disaster reduction conference, Davos, Switzerland, 27 August-1 September 2006, pp 909-912 
Rickenmann D, Hürlimann M, Graf C, Näf D, Weber D (2001) Murgang-Beobachtungsstationen in der Schweiz. Wasser Energ Luft 93(1/2):1-8

Romang H, Hegg C, Gerber M, Hilker N, Dufour F, Rhyner J (2007) IFKIS-Hydro-Informations- und Warnsystem für hydrologische Naturgefahren. Wasser Energ Luft 99(2):129-132

Schlunegger F, Badoux A, Gwerder C, Schnydrig D, Rieke-Zapp D, Molnar P, McArdell BW (in press) Limits of sediment transfer in an alpine debris-flow catchment, Illgraben, Switzerland. Quaternary Science Reviews

Schmid F, Fraefel M, Hegg C (2004) Unwetterschäden in der Schweiz 1972 bis 2002: Verteilung, Ursachen, Entwicklung. Wasser Energ Luft 96(1/2):21-28

Sidle RC, Ochiai H (2006) Landslides (processes, prediction and land use). Water resources monograph series, vol 18. American Geophysical Union, Washington, DC

Tanabashi Y (1998) Risk assessment and prediction of debris flow occurrence. J Jpn Soc Nat Disaster Sci 16:293-306

Wieczorek GF (1987) Effect of rainfall intensity and duration on debris flows in central Santa Cruz Mountains, California. In: Costa JE, Wieczorek GF (eds) Debris flows/ avalanches: process, recognition and mitigation. Reviews in engineering geology, vol 7. Geological Society of America, Boulder (CO), pp 93-104

Wilson RC, Wieczorek GF (1995) Rainfall thresholds for the initiation of debris flows at La Honda, California. Environ Eng Geosci 1(1):11-27

Wilson RC, Mark RK, Barbato G (1993) Operation of a real-time warning system for debris flows in the San Francisco Bay Area, California. In: Shen HW, Su ST, Wen F (eds) Hydraulic engineering '93, proceedings of the 1993 conference in San Francisco, vol 2. ASCE, New York, pp 1908-1913

Zhang S (1993) A comprehensive approach to the observation and prevention of debris flows in China. Nat Hazards 7(1):1-23. doi:10.1007/BF00595676 